\title{
Cultural cooperation between the non-aligned Yugoslavia and the neutral Finland from the 1960s to the 1980 s
}

\author{
Maja Vasiljević
}

As a direct successor to Yugoslavia, the Republic of Serbia celebrated in 2019 ninety years of diplomatic relations with Finland with an exhibition held at the Archives of Yugoslavia. With little interest in this topic even among researchers, it was not surprising that on this occasion the Finnish and Serbian foreign ministers, Pekka Haavisto and Ivica Dačić, were stuck on the general topic of EU integration of the Western Balkans, without any link to the exhibition they opened or reference to the shared past. ${ }^{1}$ Based on suggestive pictures from the Archives of President Urho Kekkonen in Niinikoski and domestic sources, the emphasis of this exhibition was on the close ties between the countries' two long-term presidents, Josip Broz Tito (1892-1980) and Urho Kaleva Kekkonen (1900-1986), ${ }^{2}$ and their mutual visits. ${ }^{3}$ Although independent Finland and the Kingdom of Serbs, Croats and Slovenes (later renamed as the Kingdom of Yugoslavia) established diplomatic ties in the interwar period, in August 1929, the subsequent Yugoslav war-torn history and the international reception of the Yugoslav wars for succession have diminished and

\footnotetext{
1 The event was accompanied by a catalogue in which the introduction, presenting the main points from the history relations between Finland and Yugoslavia, is followed only by a list of exhibition material with archival signatures, arranged according to three topics: mutual visits of presidents, cultural and educational relations, and trade agreements. See Jelena Đurišić (Ed.), Beograd-Helsinki: 90 godina diplomatskih odnosa. katalog izložbe / Belgrade - Helsinki: 90 Years of Diplomatic Relations, exhibition catalogue (Belgrade: Archives of Yugoslavia, 2019).

2 See media reports on this event: "Dačić i Havisto otvorili izložbu Beograd-Helsinki, 90 godina diplomatskih odnosa," https://www.rts.rs/page/stories/sr/story/9/politika/3680542/dacic-i-havisto-otvorili-izlozbu-beograd-helsinki-90-godina-diplomatskih-odnosa.html; http://www.diplomacyandcommerce.rs/the-exhibition-belgrade-helsinki-90-years-of-diplomatic-relations/.

3 Kekkonen, who visited Yugoslavia three times, in 1963 (Belgrade, Kotor, Cetinje, Brijuni, Dubrovnik, Split, and Pula), 1967 (also in Mostar) and 1975, was succeeded in 1981 by Mauno Koivisto (1923-2017), who also visited Yugoslavia in 1986. Tito was accompanied on his first visit to Finland in 1964 by Minister of Foreign Affairs Koča Popović (1908-1992), while the second time he went to Finland was on the occasion of the Helsinki Final Act meeting in Finlandia Palace in 1975. For a more detailed list of diplomats connected to Finnish-Yugoslav relations, see Đurišić (Ed.), Beograd-Helsinki, 10-11, 13-14.
} 
obscured the importance of earlier decades of cooperation between the Socialist Federal Republic of Yugoslavia (SFRY) and Finland in peacemaking and conflict resolution starting in the 1960s. We assume that another reason for the lack of interest in this topic is the change in the political atmosphere in Serbia in the 1990s, with a revision of history which sometimes left no room for observing the "peaceful episodes" in Yugoslav history.

As one of the first steps in the still establishing discourse about FinnishYugoslav cultural relations from the Yugoslav or Serbian perspective, we singled out the decades from the 1960s to the 1980s. Based on concrete facts from the Finnish-Yugoslav relations, we find cultural cooperation between the two countries theoretically and scientifically relevant for two reasons. First, this was the period of the most intensive relations between these two countries, which can be considered as a part of a broader context, and this also makes it more interesting for readers. The second reason is the researchers' personal intention to emphasize the often forgotten part of Yugoslav-and with that our-political and diplomatic heritage as peacemakers during the Cold War. ${ }^{4}$ In this respect, it is important to understand that the highlighted period was the only quiet episode in Yugoslav history. Yugoslavia acted in its foreign policy as a peaceful diplomatic oasis dedicated to mediation and bringing together other countries on the premises of its socialist Sonderweg, which was completely innovative even from today's perspective. ${ }^{5}$

Based on the view that small powers in the Cold War should not be underestimated, our approach to Finnish-Yugoslav cultural relations will be through the "pericentric lens," or to use the words of Croatian historian Tvrtko Jakovina, through the perspective of the "third side in the Cold War." ${ }^{\circ}$ In this sense, Jakovina observed: "The Cold War can be viewed through pericentric glasses: peripheral, small and less developed countries were often catalysts or initiators of Cold War conflicts. Therefore, analyzing the relations between the North and the South,

\footnotetext{
4 For a pericentric perspective of the Cold War, see Tony Smith, "New Bottles for New Wine: A Pericentric Framework for the Study of the Cold War," Diplomatic History 24/4 (2000): 567-591.

5 The innovative approach of the SFRY and its leader Tito in the Cold War bloc division has been illuminated from different perspectives by numerous scholars, especially historians interested in Tito's historical "No" to Stalin, as well as by authors who primarily focused on the foreign policies in this period. On the main premises of the SFRY's foreign policy, see Tvrtko Jakovina, Treća strana Hladnog rata [The Third Side in the Cold War] (Zagreb: Fraktura, 2011); Marija Krstić, "SFR Yugoslavia during the Cold War and current Serbian foreign policy," Anthropology: Journal of the Center for Ethnological and Anthropological Research 11/1 (2011): 21-44; John R. Lampe, Yugoslavia as History. Twice There Was a Country (Cambridge: Cambridge University Press, 2000), 207-252; Leo Mates, Medunarodni odnosi Socijalističke Jugoslavije [The International Relations of Socialist Yugoslavia] (Belgrade: Nolit, 1976); Branko Petranović "Otpor monolitizmu u Komunističkom pokretu i vanblokovska politika Jugoslavije [Resistance to monolithism in the Communist movement and the non-aligned policy of Yugoslavia]," in Istorija Jugoslavije 1918-1988: Socijalistička Jugoslavija 1945-1988. Vol. III (Belgrade: Nolit, 1988), 357-379.

6 Cf. Jakovina, Treća strana Hladnog rata.
} 
rather than the East and the West, allows us to better understand the Cold War. Small states have often played an important role in international relations, and their whims and behavior have forced superpowers to make moves they would otherwise not have made." 7 Elevating this into a strategy, finding interest in the periphery of the global Cold War process or multilayered phenomenon, which somehow forces superpowers, the Yugoslav and Finnish presidents' similar values of "non-alignment" and "neutrality" in foreign policy brought them to the principle of pacifism, opposing the arms race and searching for other ways of cooperation between European countries.

We agree with Finnish historians Pauli Kettunen and Joana Aunesluoma, who propose three levels of analysis for the Cold War phenomenon. On the first level, the Cold War is a political and military confrontation between the Eastern and the Western Bloc, dominated by the Soviet Union and the United States, respectively. The second level of analysis pertains to the conflict between socioeconomic systems-socialism and capitalism-and the third to the conflict between political approaches, including democracy, citizenship and human rights, that is the rivalry between different visions of human action and relations between individuals, the state and the society. ${ }^{8}$ As we can see from earlier research on this topic, cultural cooperation is also a special form of scientific abstraction in the discourse on the Cold War, and cultural cooperation as an integral part of a state's foreign policy is the most commonly addressed topic linking culture and the Cold War. ${ }^{9}$ However, studying culture in the context of the Cold War is complex, and authors usually focus on all types of communication between different countries, citizens, nations and their delegates (artists, scholars, performers in the case of music and theatre) who had connection to global political events. Still, even with enormously rich and popular discourse on culture and Cold War relations, it remains the task of researchers to first distinguish the different angles and interests of different countries from each other, as well as the channels of their cultural communication, which allows them to then explore the possibilities for comparative research.

Therefore, in order to conduct an in-depth analysis of the Finnish-Yugoslav cultural cooperation from the 1960s through the 1980s, we first collected data on their cultural cooperation in general. Research took us from official reports published in the journal Jugoslovenski pregled (Yugoslav Survey) and a rich collection of press-clipping material from all newspapers and magazines of former Yugoslavia, archived at the

7 Ibid., 24.

8 Cf. Pauli Kettunen, Joana Aunesluoma, "History in the Cold War and the Cold War in the Present," in The Cold War and the Politics of History, edited by Joana Aunesluoma, Pauli Kettunen (Helsinki: Edita Publishing Ltd, University of Helsinki, Department of Social Science History, 2008), 11-14.

9 Cf. Maja Vasiljević, "View to Cold War Through Pericentric Lenses: Tito’s Yugoslavia and Kekkonen's Finland," Limes plus (Special edition on the Cold War) 1 (2013): 12-13. 
Documentation Department of Radio Belgrade under "Relations between Yugoslavia and Finland," to program records of the main cultural institutions. ${ }^{10}$ Finally, we had to fill the gaps in the mentioned sources with extended research into political discourse, where we found the missing answers. ${ }^{11}$ In this phase, we collected data as mentioned as a sort of starting point for studying cultural diplomacy: all types of communication between different countries, citizens, nations, and their delegates.

In the second phase, we singled out (1) the main issues that guided the positions of Finland and Yugoslavia in the multilayered Cold War divisions, and then (2) the main similarities between them. Specifically, we were looking for these two points from the perspective of their influence on culture. It is interesting to note that both countries shared the same problematic issues (with a high probability of influencing cultural policies) of having to navigate in the hot-and-cold relations with the Soviet Union, and only then staying secure in the middle between the East and West.

In this sense, it is interesting to explore how these two seemingly very different states-the communist one-party and federal Yugoslavia and the Northern European multi-party Republic of Finland, which had historically been part of Russia-sought their place symbolically viewed as outside the paradigm of the Iron Curtain. Surprisingly, they had a similar approach to the Cold War, with their main rule being to try and cut the Iron Curtain with their peculiar and brave ideas and a strategy of maintaining a neutral position in the overall division. This observation and understanding of the "painful" issues for Finland and Yugoslavia led us to the consideration about the enormous importance of Russian classical music for both countries, or the influence of Byzantine art, or any other art where historical connections with Russia were obvious. In doing so, we understood how complex and blurred the macro and micro levels of research were in this case, and how important it is to hold onto exact facts. Therefore, this paper is focused specifically on how and on what grounds Finland and the SFRY established their cultural cooperation in the turbulent times of the global bloc division. In this sense, we focused on the question how macro-political events, concepts, values etc. influenced an aspect of the Cold War that is more on the micro level-cultural diplomacy.

\footnotetext{
10 Since our focus here are only the results of cultural cooperation between Finland and Yugoslavia, readers interested in the complete process of establishing the practice of agreements and organizing issues of cultural cooperation should see the Archives of Yugoslavia [Arhiv Jugoslavije (AJ)], Yugoslav Commission for Cooperation with the UN on Education, Science and Culture [Jugoslovenska Komisija za saradnju sa OUN za prosvetu, nauku i kulturu] (534); AJ, Federal Commission for International Cultural Links [Savezna komisija za međunarodne kulturne veze] (559).

${ }^{11}$ For more on Finnish foreign policy, see Rinna E. Kullaa, Non-Alignment and Its Origins in Cold War Europe: Yugoslavia, Finland and the Soviet Challenge (London: I. B. Tauris, 2012); Pauli Laitinen, "Međunarodni ekonomski odnosi Finske u razdoblju od 1956. do 1975. godine [The international relations of Finland in the period from 1956 to 1976]," In Urho Kekkonen: Borac za mir, edited by R. Vukadinović (Zagreb: Globus, 1977), 143-164.
} 
The basis for cultural cooperation between Finland and Yugoslavia from the 1960s to the 1980s lay in the understanding of the key concepts of their foreign policy- "neutrality" and "non-alignment." On the general level, Tito and Kekkonen agreed on the most important foreign policy concepts they promoted from the 1960s-neutrality in the case of Finland and non-alignment in the case of Yugoslavia. Rinna Kullaa, a leading expert on Eastern European and Russian foreign policy from Columbia University and the only scholar focusing on the Yugoslav-Finnish political connections concluded in her $\mathrm{PhD}$ thesis that the concept of neutrality was the basis for the split between Tito and Stalin, and came before the concept of non-alignment. ${ }^{12}$ Kekkonnen started to support the idea of non-alignment after his meeting with Tito in 1963, when Tito explained to him that it was "incorrect to understand the Belgrade Conference in 1961 as an attempt to create a third bloc." ${ }^{13}$ As president of a country at the crossroads between the East and West, Kekkonen easily noticed many similarities with Tito's ideas, particularly in terms of the so-called non-bloc management policy. They agreed as opponents of nuclear experiments and the arms race, and finally on the "policy of non-alignment and peaceful co-existence." 14

Although Tito and Kekkonen remain controversial figures in research between the East and the West in the given historical period, we have to emphasize for the purpose of this paper that the personal tastes of these authoritarian leaders were followed by artists and cultural activists. In line with this, the field of cultural cooperation was completely under the influence of the mainstream political constellations and thus guided by the two leaders, which was typical of this "era of presidents." 15

Similarities between these two countries and leaders were reflected in the concepts, establishment and activities of two important political projects/bodies - the Non-Aligned Movement (NAM) and the Conference on Security and Cooperation in Europe (CSCE). ${ }^{16}$ In both these projects, Finland and Yugoslavia

\footnotetext{
12 See more in Rinna E. Kullaa, "From the Tito-Stalin Split to Yugoslavia's Finnish Connection: Neutralism before Non-Alignment, 1948-1958," (PhD diss., University of Maryland, 2008).

${ }^{13}$ Cf. Rinna E. Kullaa, "The Birth and Development of the CSCE: Finnish and Yugoslav Models for Neutrality in the Early Cold War," in From Helsinki to Belgrade: The First CSCE Follow-up Meeting and the Crisis of Détente, edited by Vladimir Bilandžić, Dittmar Dahlmann, Milan Kosanović (Internationale Beziehungen: Theorie und Geschichte, 10. Gottingen: Bonn University Press, 2012), 46.

${ }^{14}$ For more on the topics they agreed on, see "Odnosi Jugoslavije i Finske [Relations between Yugoslavia and Finland].” Jugoslovenski pregled 12 (1966): 483.

${ }^{15}$ For more on Kekkonen's foreign policy and approach to politics, see Radovan Vukadinović (Ed.), Urho Kekkonen: Borac za mir [Urho Kekkonen: A Peace Fighter] (Zagreb: Globus, 1977).

${ }^{16}$ See more in Vladimir Bilandžić, Dittmar Dahlmann, Milan Kosanović (Eds.), From Helsinki to Belgrade: The First CSCE Follow-up Meeting and the Crisis of Détente (Internationale Beziehungen: Theorie und Geschichte, 10. Gottingen: Bonn University Press, 2012).
} 
as small powers acted as mediators, collaborators or assistants of great powers, or even the joining element for numerous other countries-like Tito with the Non-Aligned Movement or the CSCE for security issues. ${ }^{17}$ Strong political ties from the 1950s helped the two countries easily establish cultural diplomacy in the 1960s.

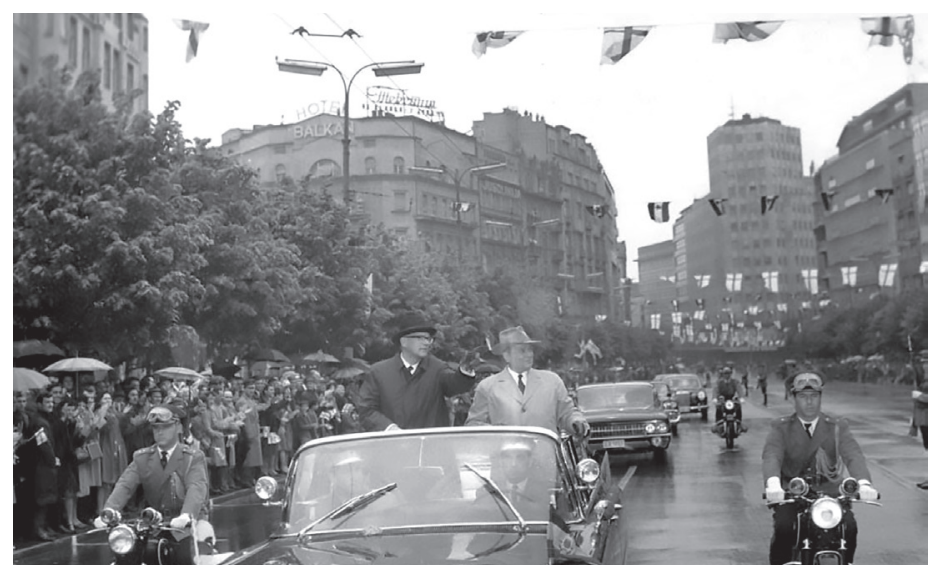

Figure 1. Kekkonen and Tito driving through the Terazije square in Belgrade on May 5, 1963. ${ }^{18}$ Archives of President Urho Kekkonen, 6-78-1963 Yugoslavia 0076.

Official institutional cooperation between Finland and the SFRY developed after mutual visits of their presidents and after agreements were signed. First, during Kekkonen's visit to Yugoslavia in 1963 and Tito's 1964 visit to Finland, the two leaders agreed on cooperation with non-aligned countries in the field of industry, and in addition, signed a number of agreements on international transport, health and other areas, but without establishing economic relations. Therefore, we can see that the process was hard and diplomacy-driven. A report in the journal Jugoslovenski pregled says the following of their relations from 1966 to 1975:

In spite of very good political relations and mutual interests for development of industrial, technical and scientific cooperation and joint presence on third markets, actual economic cooperation is not carried out in

\footnotetext{
17 The Helsinki Process directly lead to the Belgrade follow-up conference and the establishment of the CSCE, which was later succeeded by the Organization for Security and Cooperation in Europe (OSCE). This fact is often forgotten, along with Yugoslavia's role as an allied country in this project. In addition, good insight into the foreign policies of these two countries can be gained by looking into the events between the conferences in Helsinki in 1973 and the Belgrade meetings of 1977-1978. For an in-depth discussion on this issues, see Kullaa, "The Birth and Development of the CSCE."

${ }^{18}$ Cf. Đurišić, Beograd-Helsinki, 44. This photograph is kept in the Archives of President Urho Kekkonen in Niinikoski.
} 
accordance with the abilities and needs of the two countries' economies, although significant progress has been made. ${ }^{19}$

Although the economy was without a doubt an important topic for the two countries caught between the interests and agreements of the East and West, it is interesting to note that that soft power or cultural diplomacy ${ }^{20}$ made better, easier and faster progress, not only in the abovementioned nine-year period, but also until the end of the 1980s. The same report reveals how Finland and Yugoslavia cooperated in this period in the field of science, but also in high art practices, such as visual arts, architecture, literature, music and film. Therefore, apart from successful diplomatic cooperation in politics, these two countries were connected institutionally in the field of culture for decades. Even before formal agreements were signed, we can find data about institutional dialogue between these two countries, starting as early as 1960 . One of the first artistic events was a concert held on April 15, 1959 at the Kolarac Hall in Belgrade, when internationally renowned Finnish opera singer, bass-baritone Kim Borg (1919-2000), accompanied by Slovenian pianist Pavel Šivic (1908-1995), performed songs of Mozart, Haydn, Schubert, Ravel, Sibelius, and Mussorgsky. ${ }^{21}$

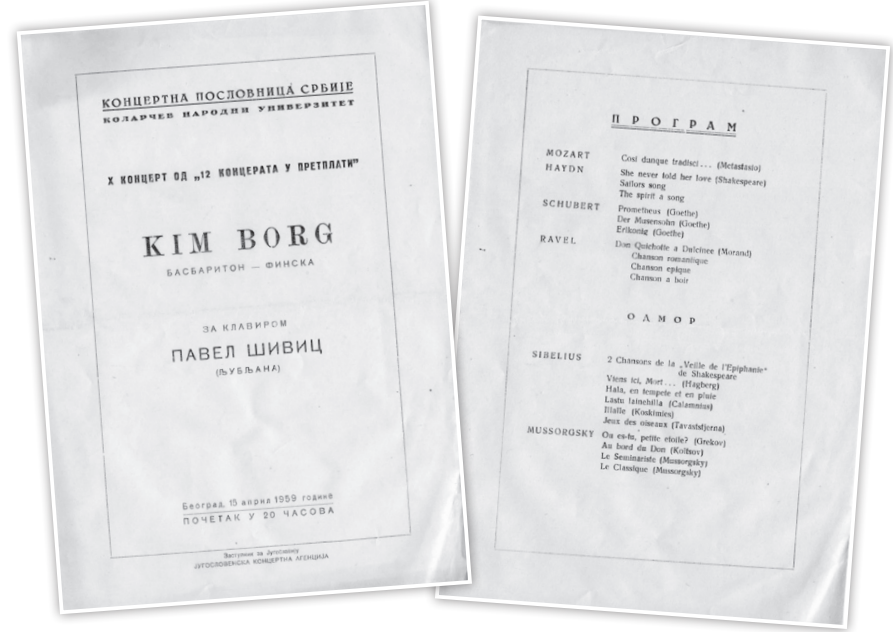

Figure 2. Concert program of Kim Borg and Pavel Šimic, April 15, 1959.

Milenko Petković's private collection, https://jugosvirke.wordpress.com/.

\footnotetext{
${ }^{19}$ Cf. "Odnosi Jugoslavije i Finske [Relations between Yugoslavia and Finland]," Jugoslovenski pregled 3 (1975): 127.

20 See Milton C. Cummings, Cultural Diplomacy and the United States Government: A Survey (ICD Institute for Cultural diplomacy, Centre for Arts and Culture, 2003).

${ }^{21}$ Like many other Finnish musicians who returned to Yugoslavia more than once, Borg performed again in Belgrade in 1968, according to program reports of the Jugokoncert agency from Belgrade.
} 
It is interesting how musicians found their way to connect even without official mediation of high political institutions. Although we found scattered musical events as proof of previously existing Finnish-Yugoslav artistic respect, official cultural exchange between Finland and the SFRY started with literature, which was only then followed by visual arts, film, music, theater and science. In 1966, the two countries signed their first formal plan for cooperation in the areas of culture and science, renewed in 1973 when Finland and Yugoslavia signed the Agreement on Bilateral Cooperation in the Fields of Culture, Science and Education. ${ }^{22}$ This cooperation continued through the 1980s, and was confirmed with the Agreement on Cultural Cooperation (1985-1987). But most importantly, the two countries established a general strategic plan for cooperation, covered by the Program for Cultural Cooperation between Finland and Yugoslavia.

On the one hand, we can conclude from the timeline of their cooperation that the first step in their cultural exchange were translations of their respective leading literary works; Finnish to Serbian and Serbian to Finnish. Books by writer and diplomat Ivo Andrić (1892-1975) were groundbreaking in this respect. For example, his novel $\mathrm{Na}$ Drini ćuprija (The Bridge on the Drina, 1945) was translated into Finnish even before he was awarded the Nobel Prize in Literature in 1961, when translations of his Gospodica (The Young Lady) and Travnička hronika (Travnik Chronicle) also came out. Apart from Andrić, books by Miodrag Bulatović (1930-1991) and Dobrica Ćosić (1921-2014) were also translated into Finnish. Likewise, numerous classical or contemporary Finnish writers were translated into Serbian. Probably the most popular example is the novel Ihmiset suviyössä (People in the Summer Night, 1934) by Frans Eemil Sillanpää (1888-1964), the Nobel Prize laureate of 1939. Other translations include Tuntematon sotilas (The Unknown Soldier, 1954) by Väinö Linna (1920-1992), The Adventurer (Mikael Karvajalka, 1948), The Wanderer (Mikael Hakim, 1949) and Turms kuolematon (The Etruscan, 1955) by Mika Waltari (1908-1978), Seitsemän veljestä (Seven brothers, 1870) by Aleksis Kivi (1834-1872) and the documentary novel Raft of Despair (1954) by Ensio Tiira (1929-1981). The linguistic exchange between these two countries was finally crowned in the period of the Agreement on Cultural Cooperation (1985-1987), including a celebration of the $200^{\text {th }}$ birthday of language reformist and linguist Vuk Stefanović Karadžić (1787-1864), as well as events related to the Finnish language in Novi Sad and to Serbo-Croatian in Helsinki.

On the other hand, looking through all the activities within the Program for Cultural Cooperation between Finland and Yugoslavia, we noticed a predominance of exchanges of visual and applied arts exhibitions (Table 1).

\footnotetext{
${ }^{22}$ On agreements in this period, see “Odnosi Jugoslavije i Finske," (1975).
} 


\begin{tabular}{|c|c|c|}
\hline \multirow{2}{*}{ Year } & Name of event & \multirow{2}{*}{$\begin{array}{l}\text { Artist exhibited } \\
\text { and main exhibits }\end{array}$} \\
\hline & Place of event & \\
\hline \multirow[t]{2}{*}{1964} & Finnish form & \multirow{2}{*}{ Alvar Alto } \\
\hline & Museum of Arts and Crafts in Zagreb & \\
\hline \multirow[t]{2}{*}{1965} & Contemporary Finnish visual art & \multirow{2}{*}{$\begin{array}{l}\text { Juhani Linnovaara (1934), Tuomas vom } \\
\text { Boehm (1916-2000) }\end{array}$} \\
\hline & $\begin{array}{l}\text { Museum of Contemporary Art in } \\
\text { Belgrade }\end{array}$ & \\
\hline \multirow[t]{2}{*}{1965} & $\begin{array}{l}25 \text { years of the Dubrovnik Summer } \\
\text { Festival }\end{array}$ & \multirow{2}{*}{$\begin{array}{l}\text { Organized by the Ministry of Culture } \\
\text { and featuring Finnish minister Marjatta } \\
\text { Väänänen as keynote speaker }\end{array}$} \\
\hline & Novi Sad, Stockholm and Helsinki & \\
\hline \multirow[t]{2}{*}{1966} & Finnish Applied Arts & \\
\hline & $\begin{array}{l}\text { Exhibition space on Masaryk Street } \\
\text { in Belgrade }\end{array}$ & \\
\hline 1974 & $\begin{array}{l}\text { Review of Contemporary Yugoslav Art } \\
\text { Helsinki, Tampere }\end{array}$ & \\
\hline \multirow[t]{2}{*}{1975} & & \multirow{2}{*}{$\begin{array}{l}\text { 15 Finnish graphic artists from Lahti, } \\
\text { including Kosti Ahonen (1920), Olavi } \\
\text { Rikle (1917), Rauno Salinnen (1949), Mati } \\
\text { Koskel, Ani Ukonen, Antero Olin, Enja } \\
\text { Markannen } \\
\end{array}$} \\
\hline & $\begin{array}{l}\text { Graphic Collective Gallery in } \\
\text { Belgrade }\end{array}$ & \\
\hline \multirow[t]{2}{*}{1977} & 15 Finnish artists & \multirow{2}{*}{$\begin{array}{l}\text { Visual art and sculptures by Juhani } \\
\text { Linnovaara, Rainno Haitinen, Juhani } \\
\text { Hari, Juhani Hakalahti, Kirsti Muinnonen, } \\
\text { Kiimo Piiko }\end{array}$} \\
\hline & $\begin{array}{l}\text { Museum of Contemporary Art in } \\
\text { Belgrade }\end{array}$ & \\
\hline \multirow[t]{2}{*}{1977} & 15 Finnish artists & \multirow{2}{*}{$\begin{array}{l}\text { Hakalahti Juhani, Harri Juhani, Reino } \\
\text { Hietanen, Outi Ikkala, Antti Jantunen, } \\
\text { Kauko Lehtinen, Juhani Linnovaara, Ukri } \\
\text { Merikanto, Kirsti Muononen, Marika Mäkelä, } \\
\text { Arto Pennanen, Gunnar Pohjola, Kimmo } \\
\text { Pyykö, Pauli Pyykölä and Kain Tapper }\end{array}$} \\
\hline & Yugoslav Portrait Gallery in Tuzla & \\
\hline \multirow[t]{2}{*}{1977} & Helsinki & \multirow{2}{*}{ Alvar Alto's Finlandia (1971) plan } \\
\hline & Center for Culture in Belgrade & \\
\hline \multirow[t]{2}{*}{1980} & $\begin{array}{l}\text { Tradition and identity-Architecture } \\
\text { in Finland }\end{array}$ & \multirow{2}{*}{$\begin{array}{l}300 \text { exhibits, including Eliel Saarinen's } \\
\text { urbanistic plan for Canberra, Willy Revel, } \\
\text { Kaija and Heikki Siren, Alvar Alto, Timo } \\
\text { Penttilä }\end{array}$} \\
\hline & $\begin{array}{l}\text { Museum of Contemporary Art in } \\
\text { Belgrade }\end{array}$ & \\
\hline
\end{tabular}

Table 1. Exhibitions as part of cultural cooperation between Finland and Yugoslavia 1964-1985 (selection). ${ }^{23}$

\footnotetext{
${ }^{23}$ For more details on these events, see the following articles from the Press clipping collection of Yugoslav newspapers and magazines kept at the Documentation Department of Radio Belgrade in the Yugoslavia and Finland Fond: Zoran Markuš, "Savremena finska umetnost [Contemporary Finnish art]," Borba (March 10, 1977); Prvoslav Mitić, "Dva smera finske umetnosti [Two directions
} 
Apart from the exchanges of exhibitions of visual and applied arts, the Program for Cultural Cooperation included the organization of interdisciplinary events between Finland and the SFRY, with mix of both high and popular art. While art exhibitions targeted mainly diplomatic representatives and art experts, these interdisciplinary festival-type events attracted the broader public from the two countries and received more attention in the public space. An institution that also brought together a diverse audience and merged high artistic practices with more popular ones was the Suomi-Jugoslavia seura (the Society of Friendship between Finland and Yugoslavia). ${ }^{24}$ Founded already in 1957, long before the official cultural agreements of the two countries, Suomi-Jugoslavia seura organized numerous events for decades. To highlight only one of them, the most important one of them was the Yugoslav Week in Finland, with an exhibition on the 25 years of the Dubrovnik Summer Festival. The event also featured a guest performance by soloists of the Zagreb opera, baritone Vladimir Ruždjak (1922-1987)25 and soprano Nada Siriščević (1934-2012), later married to Ruždjak, while one of the most distinguished chamber music ensembles from former Yugoslavia, the Zagreb Quartet, also gave a concert in the Finnish capital.

The Days of Yugoslavia in March 1989 were one of the last such mixed events before the dissolution of the SFRY that were organized as part of this program, in this case with the participation of the International Women's Club. The event had a strong focus on folklore, and ambassadors' wives dressed in the folk costumes of their friendly country.

\footnotetext{
of Finnish art]," Borba (April 17, 1964); Prvoslav Mitić, "Savremeno finsko slikarstvo - doživljaj finske umetnosti [Contemporary Finnish visual art-experience of Finnish art]," Borba (May 25, 1965); Darko Popović, "Obe strane granice: Tradicija i identitet - Arhitektura u Finskoj [Both sides of the border: Tradition and identity-Architecture in Finland]," Nin (March 16, 1980); "Izložba 'Finski oblik' u Muzeju za umetnost i obrt u Zagrebu [Exhibition "Finnish Form" in the Museum of Arts and Crafts in Zagreb]," Vjesnik (November 16, 1966); "Kći Baltičkog mora [Daughter of the Baltic Sea]," Politika (June 13, 1977); "Retrospektiva finskog graditeljstva od srednjeg veka do danas [Retrospective of Finnish architecture from the Middle Ages until today], Borba (February 25, 1980); "Finska primenjena umetnost [Finnish applied arts]," Politika (October 8, 1966).

24 The organization's activities were described on the occasion of its $25^{\text {th }}$ anniversary in Hannes Markkula, Armi Sarvaslahti, Helena Paalanen. Suomi-Jugoslavia Seura 25 Vuotta: Juhlajulkaisu [The Finnish-Yugoslav Society 25 Years: Celebration] (Helsinki: Suomi-Jugoslavia seura, 1983). The society was succeeded in 2000 by the Serbian-Finnish Society (Serbialais-Suomalainen Seura). ${ }^{25}$ Ruždjak had won international acclaim, having sung at Metropolitan Opera from 1962 to 1964 and with more than two thousand opera performances in his main opera houses of Zagreb and Hamburg from the 1950s to the mid-1970s.
} 


\begin{tabular}{|c|l|l|}
\hline Year & \multicolumn{1}{|c|}{ Name of event } & \multicolumn{1}{c|}{ Program } \\
\hline 1975 & $\begin{array}{l}\text { Yugoslav Culture } \\
\text { Days }\end{array}$ & $\begin{array}{l}\text { Exhibition on the Dubrovnik Summer Festival, and } \\
\text { guest performances by the Zagreb Quartet and Zagreb } \\
\text { opera soloists Vladimir Ruždjak and Nada Siriščević }\end{array}$ \\
\hline 1981 & $\begin{array}{l}\text { Yugoslav Week in } \\
\text { Finland }\end{array}$ & $\begin{array}{l}\text { Music and visual arts: Concerts of 2 Finnish choirs, } \\
\text { Serbian violinist Maja Jokanović; 3 exhibitions and a } \\
\text { screening of the war movie Occupation in 26 images } \\
(\text { Okupacija u 26 slika }) \text { by Lordan Zafranović }\end{array}$ \\
\hline 1985 & $\begin{array}{l}\text { 200 years Vuk } \\
\text { Stefanović Karadžićs } \\
\text { birth (Helsinki) }\end{array}$ & $\begin{array}{l}\text { Days of Yugoslavia } \\
\text { Exhibition on everyday village life; a movie on World } \\
\text { War memorials }\end{array}$ \\
\hline
\end{tabular}

Table 2. Mixed events as a result of the Finnish-Yugoslav friendship in the 1970s and the 1980s. ${ }^{26}$

Books and art works traveled easily to Yugoslav and Finnish audiences and institutions, but live contact of artists was the other side of cultural exchange of opinions and values between the "land of a thousand lakes" and the "country of brotherhood and unity." According to the Yugoslav press, the most common guest artists in Yugoslavia were painters, graphic designers and architects from Helsinki, Tampere, Jahta and Kuopio. Nevertheless, live music performances, as artistic expressions in real time and in front of the audience, had a special place in the cultural exchange between Finland and Yugoslavia.

Musicians from former Yugoslavia started visiting Finland at the beginning of the 1960s, but in the context of successful subsequent cooperation it is important to mention the mutual visits of representatives of cultural institution. To set the ground for actual musical exchange, opera and theatre institutions from the two countries first exchanged visits, such as those of Finnish conductor Arvi Kivimaa (1901-1984) and Milan Bogdanović, the head of the Belgrade National Theatre. As a result of their visits, numerous musical performers gave concerts in the other country. Their bilateral dialogue covered many different musicians, such as pianists, violinist, opera singers, chamber ensembles, etc.

As pioneers of this cultural exchange with Finland, Yugoslavia sent in 1960 two renowned musicians: opera singer Miroslav Čangalović (1921-1999), who was internationally renowned for his performance of Russian music, and Živojin Zdravković (1914-2001), the conductor of the Belgrade Philharmonic Orchestra

\footnotetext{
26 See Press clipping collection of Yugoslav newspapers and magazines kept at the Documentation Department of Radio Belgrade.
} 
and the founder of the Symphonic Orchestra of Cairo, who received a prestigious prize in Germany as one of the best performers of Tchaikovsky. In 1963, the most prominent Croatian chamber string orchestra, the Zagreb Soloists, with its conductor and founder of Italian origin Antonio Janigro (1918-1989) performed in Helsinki.

To mark the centenary of the birth of the most important Finnish composer, Jean Sibelius (1865-1957), a number of concerts were organized in Yugoslavia in 1965. Ten years later, among other compositions, music by Sibelius was performed by the Finlandia Quartet at the most important festival in former Yugoslavia-the Dubrovnik Summer Festival. ${ }^{27}$ In the 1980s, Serbian violinist Maja Jokanović (1953) performed Sibelius' Violin Concerto at the Sibelius Music Academy in Helsinki, and performed as a guest in Finland several more times.

There were also significant visits to Yugoslavia by Finnish classical musicians. Maija-Liisa Pohjola (1936), who is considered one of the best Scandinavian pianists of all time and is still active, performed at the Kolarac Hall in Belgrade in 1966.28 Pohjola's recital program included contemporary Finnish composers like Erik Bergman (1911-2006), Kalevi Ensio Aho (1949) and Mikko Heiniö (1948). As part of the cultural exchange, cellist Arto Noras (1942), one of the most distinguished classical musicians from Finland, performed in Belgrade several times. In 1979, he played at the Kolarac

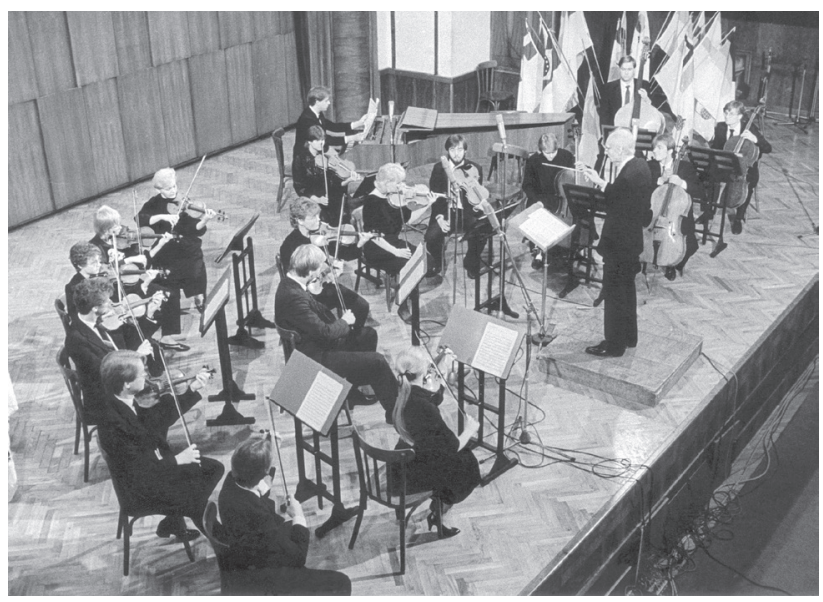

Figure 3. Finnish chamber orchestra on International Jeunesses Musicales Competition in Belgrade, Kolarac Hall. IJMC Archive-Jeunesses Musicales Belgrade, https://muzicka-omladina.org/takmicenje/rhiv.html?start=5.

\footnotetext{
${ }^{27}$ Established in 1969, the Finlandia Quartet was dedicated to performing and recording the music of Finnish composers: Jean Sibelius, Joonas Kokkonen (1921-1996), Aulis Sallinen (1935) and Einojuhani Rautavaara (1928-2016). Members of the Finlandia Quartet performing in Dubrovnik were Olavi Pälli (first violin), Jussi Pesonen (second violin), Esa Kamu (viola) and Heikki Rautasalo (cello). See Ruth-Esther Hillila, Barbara Blanchard Hong, Historical Dictionary of the Music and Musicians of Finland (Westport, Connecticut/London: Greenwood Press, 1997), 73.

${ }^{28}$ According to program records in the archives of the Jugokoncert concert agency.
} 
Hall with our prominent pianist and pedagogue Andreja Preger (1912-2015). A year earlier, Noras performed at the Dubrovnik Summer Festival. Other musicians from Finland who visited Belgrade included conductor Paavo Rautio, Matti Tuloisela and Arvo Airaksinen. Finally, the Sibelius Academy Chamber Orchestra, under the baton of conductor and violinist Tuomas Jaakko Haapanen (1924), performed and won second prize at the International Jeunesses Musicales Competition in Belgrade in 1986. ${ }^{29}$

\section{Conclusion}

Before making our final remarks on the cultural diplomacy between Finland and Yugoslavia, we have to briefly return to some of the issues outlined in the introduction. As already mentioned, the new circumstances following the dissolution of the SFRY implied a different approach to foreign policy in successor states. The image of war-torn successor states changed in the international perspective and relations with other countries. To recall this moment of change, we can use example the Finnish folk rock band Slobo horo from Tampere, which uses not only Serbian folklore from the western part of the country, but also taught that include in a band name reference to then Serbian President Slobodan Milošević, so their first album "Mastika" was banned on radio and TV stations in 1992. ${ }^{30}$ This illustrates quite clearly how the Finnish public quickly reacted to the influences of nationalistic figures and their values. We can confirm that in the 1990s the interest in relations between Finland and former Yugoslav republics decreased.

Keeping in mind the entire process of cultural cooperation between Finland and Yugoslavia, it is very important to emphasize the differences in these two countries' approach to more controversial artistic practices, namely to a wide range of avant-garde practices in contemporary art in the late 1980s and in popular culture from the start of the 1990s. In addition to the abovementioned practices in contemporary visual arts, it is more scientific rewarding to conclude this retrospective of events that marked the three decades of Yugoslav-Finnish friendship with theatrical practices.

It was obvious that Finland was fascinated by the enormous amount of energy that the SFRY invested in the construction of a prestigious image of the state at international events, such as the Dubrovnik Summer Festival or the Belgrade International Theatre Festival (BITEF). ${ }^{31}$ Considering many examples from the men-

\footnotetext{
${ }^{29}$ See IJMC Archive-Jeunesses Musicales Belgrade, https://muzicka-omladina.org/takmicenje/ rhiv.html?start $=5$.

${ }^{30}$ For more on this band, see Dragan Bisenić "Slobo horo," Nin (January 27, 2000): 51-52. This band was formed in 1986.

${ }^{31}$ In this sense, we can highlight the Finnish theatre play Kalevala directed by Jorma Uotinen and performed by the theatre troupe of the Helsingin Kaupunginteatteri at the $21^{\text {st }}$ Belgrade International Theatre Festival in 1987. For more on this event, see "Bitef 'Kalevala'," Oslobođenje (September 16, 1987) in the Press clipping collection of Radio Belgrade in the Yugoslavia and Finland Fond.
} 
tioned festivals we conclude that "Yugoslavia was the only country where something impossible was possible - to see theatres from the Soviet Union and Czechoslovakia appear on the same festival stage immediately after the aggression of the Warsaw Pact forces on the democratically oriented government in Czechoslovakia." ${ }^{2}$ In this sense, Finland's approach to Yugoslavia as a common ground for new artistic practices and an inspiration for establishing more freedom for artists in the public space. The SFRY, on the other hand, saw Finland as an inspiration in architecture, especially the works of Alvar Arto, but also in other fields of visual arts.

Moreover, we can conclude that the presentation of Yugoslav visual artists, literature and folklore in Finland was meant for the ordinary people, as well as academicians, art experts, diplomats, etc. Reviewing the encounter of Finnish artists/ artistic practices with the Yugoslav public, we can confirm a common perception of Yugoslavia as an oasis for avant-gardes practices, that is for a different kind of freedom as a result of its openness to even different ideological positions with respect to art. In music, as presented in this paper, the Finnish-Yugoslav relations reflected a complete reproduction of the "painful" issues in the Cold War division that influenced the culture of these two countries. In addition, both countries were rich in musicians that represented the Russian operatic repertoire, or in the case of Yugoslav musicians, were fighting for a position of renowned performers of the Classical and Romantic music repertoire tailored to the taste of the Western European public and institutions. In this respect, we cannot take for granted the important fact that "classical music, theatre, ballet, fine art [...] held a central place in the Soviet Union's enlightenment project at home, as well as in its self-projection abroad as the savior of European civilization." 33

The rich discourse on the importance of music, film and literature as part of the cultural cooperation or "cultural war" between the great powers, the US and the USSR, was in our case an inspiration for research on small-scale power management-cultural cooperation policies. The discourse on concrete diplomatic projects with jazz musicians as ambassadors of the United States and Hollywood as the strongest influence in the previous history, served as an inspiration for in-depth research on the Finnish and Yugoslav cultural crossroads, which we observe as relatively autonomous from the clashes of great powers, and guided by their local interest and artistic resources.

\footnotetext{
${ }^{32}$ Cf. Jovan Ćirilov, "Beograd i Bitef [Belgrade and BITEF]," Limes plus (Special edition on the Cold War) 1 (2013): 165.

${ }^{33}$ Susan E. Reid, "Foreword," in Music, Art and Diplomacy: East-West Cultural Interactions and the Cold War, edited by Simo Mikkonen, Pekka Suutari (London: Routledge, 2017), xiii.
} 


\section{Primary sources:}

Archival sources

Archives of the Jugokoncert Concert Agency (Belgrade)

Documentation Department of the Radio Belgrade (Belgrade): Yugoslavia and Finland Fond
Press and periodicals

Jugoslovenski pregled, Belgrade, 1957-2002

\section{Internet sources:}

IJMC Archive-Jeunesses Musicales Belgrade, https://muzicka-omladina.org/takmicenje/ rhiv.html?start=5.

\section{References:}

Aunesluoma, Joana, Kettunen Pauli (Eds.). The Cold War and the Politics of History. Helsinki: Edita Publishing Ltd, University of Helsinki, Department of Social Science History, 2008.

Bilandžić, Vladimir, Dahlmann, Dittmar, Kosanović, Milan (Eds.). From Helsinki to Belgrade: The First CSCE Follow-up Meeting and the Crisis of Détente. Internationale Beziehungen: Theorie und Geschichte, 10. Gottingen: Bonn University Press, 2012.

Bisenić, Dragan. "Slobo horo." Nin (January 27, 2000): 51-52.

Ćirilov, Jovan. "Beograd i Bitef." Limes plus (Special edition on the Cold War) 1 (2013): 165-168.

Cummings, Milton C. Cultural Diplomacy and the United States Government: A Survey. ICD Institute for Cultural Diplomacy, Centre for Arts and Culture, 2003.

Đurišić, Jelena (Ed.). Beograd-Helsinki: 90 godina diplomatskih odnosa. katalog izložbe / Belgrade-Helsinki: 90 Years of Diplomatic Relations, exhibition catalogue. Belgrade: Archives of Yugoslavia, 2019.
Eschen, Penny von. Satchmo Blows Up the World: Jazz Ambassadors Play the Cold War. London: Harvard University Press, 2004.

Hillila, Ruth-Esther, Blanchard Hong, Barbara. Historical Dictionary of the Music and Musicians of Finland. Westport, Connecticut-London: Greenwood Press, 1997.

Jakovina, Tvrtko. Treća strana Hladnog rata. Zagreb: Fraktura, 2011.

Jovanović, Vladimir. Beogradska opera u Evropi. Gostovanja od 1954 do 1969. Novi Sad: Akademija umetnosti, Prometej, 1996.

Kettunen, Pauli, Aunesluoma, Joana. "History in the Cold War and the Cold War in the Present." In The Cold War and the Politics of History, edited by Joana Aunesluoma, Pauli Kettunen, 9-18. Helsinki: Edita Publishing Ltd: University of Helsinki, Department of Social Science History, 2008.

Krstić, Marija. "SFR Yugoslavia during the Cold War and current Serbian foreign policy." Anthropology: journal of the Center for Ethnological and Anthropological Research 11/1 (2011): 21-44. 
Kullaa, Rinna E. "From the Tito-Stalin Split to Yugoslavia's Finnish Connection: Neutralism before Non-Alignment, 19481958." PhD diss., University of Maryland, 2008.

Kullaa, Rinna E. Non-Alignment and Its Origins in Cold War Europe: Yugoslavia, Finland and the Soviet Challenge. London: I. B. Tauris, 2012.

Kullaa, Rinna E. "The Birth and Development of the CSCE: Finnish and Yugoslav Models for Neutrality in the Early Cold War." In From Helsinki to Belgrade: The First CSCE Follow-up Meeting and the Crisis of Détente, edited by Vladimir Bilandžić, Dittmar Dahlmann, Milan Kosanović, 39-58. Internationale Beziehungen: Theorie und Geschichte, 10. Gottingen: Bonn University Press, 2012.

Laitinen, Pauli. "Međunarodni ekonomski odnosi Finske u razdoblju od 1956. do 1975. godine." In Urho Kekkonen: Borac za mir, edited by R. Vukadinović, 143-164. Zagreb: Globus, 1977.

Lampe, John R. Yugoslavia as History. Twice There Was a Country. Cambridge: Cambridge University Press, 2000.
Markkula, Hannes, Sarvaslahti, Armi, Paalanen, Helena. Suomi-Jugoslavia Seura 25 Vuotta: Juhlajulkaisu. Helsinki: SuomiJugoslavia seura, 1983.

Mates, Leo. Međunarodni odnosi Socijalističke Jugoslavije. Belgrade: Nolit, 1976.

“Odnosi Jugoslavije i Finske." Jugoslovenski pregled 3 (1975): 127-130.

Petranović, Branko. Istorija Jugoslavije 1918-1988: Socijalistička Jugoslavija 1945-1988. Vol. III. Belgrade: Nolit, 1988.

Reid, Susan E. "Foreword." In Music, Art and Diplomacy: East-West Cultural Interactions and the Cold War, edited by Simo Mikkonen, Pekka Suutari, xi-xiviii. London: Routledge, 2017.

Smith, Tony. "New Bottles for New Wine: A Pericentric Framework for the Study of the Cold War." Diplomatic History 24/4 (2000): 567-591.

Vasiljević, Maja. "View to Cold War Through Pericentric Lenses: Tito’s Yugoslavia and Kekkonen's Finland." Limes plus (Special edition on the Cold War) 1 (2013): 9-28.

Vukadinović, Radovan (Ed.). Urho Kekkonen: Borac za mir. Zagreb: Globus, 1977. 